\title{
Gruzy i ruiny w twórczości Józefa Ignacego Kraszewskiego
}

Magdalena Rudkowska 


\section{Magdalena Rudkowska}

\section{Gruzy i ruiny w twórczości Józefa Ignacego Kraszewskiego}

Padl w proch okrąg świata ogromny (Horacy) 1

\footnotetext{
$\mathrm{R}$ uiny nasze więcej mają przyszłości niż wasze budowy..."2. W zdaniu wyjętym z powieści Kraszewskiego My i oni (1865), kierowanym do możnowładców Rosji, przebija duma $\mathrm{z}$ dziedzictwa zapisanego $\mathrm{w}$ kształtach ruin i szczątków, dziedzictwa zakrzepłego w chwili tragicznego przełomu, podobnie jak stało się z kulturą antyczną Grecji czy Rzymu. Bolesławita zamierzył postawić przed oczyma światowej opinii publicznej polskie ruiny, zarys murów utrwalający dawne kształty. Zachowała się w nich szansa rekonstrukcji form pierwotnych. Pozwalały też wyrokować o przyszłych. Ruiny objęte takim spojrzeniem okazywały się bytami pośredniczącymi między przeszłością a przyszłością, a dzięki temu poniekąd zastępującymi teraźniejszość, której-o czym głośno w publicystyce i literaturze epoki - wlaściwie nie było ${ }^{3}$. Takiej przynajmniej, by dawała się bez wstrętu i wstydu akceptować. Gruzami tymczasem nikt się raczej nie chełpił. Raniły oczy. Niweczyły pamięć widoków. Były po prostu bezforemnym, bezksztaltnym usypiskiem ${ }^{4}$. Z gruzów nie sposób już odczytywać jakichkolwiek znaków; ani przeszłości, ani przyszłości. Ani świadectw, ani krzepiących prognoz nadziei.

Gruzy i ruiny są w naszej kulturze artystycznej metaforą paradygmatyczną ${ }^{5}$. Ewokują „sceny upadku, klęski, sieroctwa" ${ }^{6}$. Pomijając bogatą tradycję topiki ruin w literaturze XVIII i XIX wieku ${ }^{7}$,

${ }^{1}$ Pieśni II 1, 23, cyt. za: Q. Horatius Flaccus, Poezje..., tł. J. Czubek, wst. K. Morawski, Warszawa 1924, s. 63.

2 [J. I. Kraszewski], My i oni. Obrazek narysowany z natury przez B. Bolesławitę, Kraków 1902, s. 302.

${ }^{3}$ Zob. np. W. Łoziński, Zapiski literackie (III), „Dziennik Literacki” 1867, nr 46, s. 726.

4 O różnicy pomiędzy ruinami i gruzami pisze Marian Płachecki w artykule Niemcewvicz kultowy (w druku).

5 Zob. K. Stępnik, Metafory paradygmatyczne w powieściach historycznych Kraszewskiego. Okres 1833-1863, „Pamiętnik Literacki" 1987, z. 4, s. 55-80, zob. zwł. s. 74-76 (Agonia i ruina).

' J. I. Kraszewski], Bezimienna. Powieśé z końca XVIII wieku przez B. Bolestawitę, Lwów 1869, s. 4.

7 Zob. G. Królikiewicz, Terytorium ruin. Ruina jako obraz i temat romantyczny, Kraków 1993.
} 
skoncentruję się jedynie na wątku mowy ruin, bełkotu gruzów; wątku traktowanym przez Kraszewskiego wielostronnie i niejednoznacznie. W jednej ze scen powieści Krwawe znamię (Ongi1867) jej bohater, Nikodem Repeszko, dobitnie daje wyraz przekonaniu, że do kogoś, kto nie jest stąd, „gruz ten nic nie mówi”. Nie jest ani „świętościa”, ani nawet prostym „wspomnieniem”. Gruz - stopniowo, cegła po cegle, kamień po kamieniu - wchłania natura. Po insurekcji kościuszkowskiej do pałacu w Głuszy z powieści Diabeł (1855) bezlitośnie wdarł się żywioł: bruki dziedzińca zarosły trawą, pasły się na nich zwierzęta, wszystko przegniło i zzieleniało od mchów. Od zachłannych miejscowych ucierpiała natura: „na lipach świeciły zółte rany zadane przez chciwych łupu wieśniaków”, „sterczały kalekie gałęzie nielitościwie poodtrącane siekierą”. W opisach takich trudno doszukiwać się znanego choćby z Sonetów krymskich Adama Mickiewicza motywu natury triumfującej nad cywilizacją. Wszystko się ze sobą miesza w jedną bezkształtną masę; czarną, wypaloną i przemieszaną z ziemią.

Nigdzie może czas nie niszczy tak szybko jak u nas - bo mu klimat pomaga i ludzie ${ }^{10}$.

Zagładzie podlega więc wszystko — bez żadnych niosących pociechę wyjątków. Rozmywa się granica między naturą a kulturą. Obracają się w proch znaki pamięci. Salony nie mają już posadzek, z ram wyrwano portrety, w muzeum stoi szaflik blaszany, a po bibliotece zostało tylko parę okładek, zdemolowane półki i garść kurzu ${ }^{11}$. Chaotyczne usypisko szczątków nieorganicznych i organicznych włącza się w bezimienny cykl narodzin i śmierci. Pamięć, raz dana, może z czasem zostać - odjęta.

Józef Ignacy Kraszewski, wydawca historycznych świadectw, zbieracz polskich pamiątek, świadomy twórca nowych narodowych legend, nieoczekiwanie okazuje się również pisarzem niepamięci. Pisarzem szczególnie na fenomen, groźbę — i otuchę - niepamięci uwrażliwionym. Swojej litewskiej epopei nadał niemało mówiący tytuł: Anafielas (1840-1845) znaczy 'góra niepamięci'. Góra taka wznosi się też w samym centrum świata przedstawionego poematu. Pełni funkcję - na co zwracał uwagę Aleksander Tyszyński w roku 1880 - analogiczną do greckiego Styksu ${ }^{12}$.

Maurycy Mochnacki, pisząc o ruinach w roku 1825, uznał, że znaczeniem obdarzone jest to wszystko, co „nie podlega sztucznemu berłu człowieka”. Gdy czas zniszczy użyteczność przedmiotów, te „odzyskują mistyczne życie”, a samo „zniszczenie wskrzesza ich stosunki z przyrodzeniem”. Dlatego właśnie „wspaniałe budowle i gmachy milczą, lecz ruiny mówią"13.

W twórczości Kraszewskiego, zwłaszcza po roku 1863, brakuje tej pewności i zaufania w deszyfracyjne potencje ludzkiego serca i oka. Owszem, ruiny mają znaczeń więcej niz piękne gmachy. Lecz co mówią, nie zawsze wiadomo. Potrzebni są świadkowie przytomni czasom ich minionej

\footnotetext{
${ }^{8}$ Zob. J. I. Kraszewski, Krwaue znamię, Warszawa 1885, s. 41.

${ }^{9}$ Idem, Diabet. Pourieść z czasów Stanistawa Atugusta, t. 4, Lwów 1873, s. 158.

${ }^{10}$ Ibidem.

11 Por. ibidem, t. 4, s. 163.

${ }_{12}$ Zob. A. Tyszyński, J. I. Kraszeuski i jego „Pourieści historyczne”, w: idcm, Pisma krytyczne, t. 2: Pisma od roku 1866, Kraków-Petersburg 1904, s. 699.

${ }_{13}$ M. Mochnacki, O duchu i żódlach poezji w' Polszcze, w: idem, Pisma. Po raz pienuszy edycją ksiqżkou'ą objęte, wyd. i przedm. A. Śliwiński, Lwów 1910, s. 13.
} 
świetności. Nikt nieuprzedzony nawet by nie pomyślał, że w danej sali pałacu w Głuszy mieściła się kiedyś galeria sztuki. Dziś nic już o tym nie świadczyło. Ślady wymiótł do cna wieczny kolowrót życia i śmierci; kołowrót brutalny, okrutny, przerażający. Uwagę narratora przyciągaja stany pośrednie, "gmatwanina bez znaczenia" ${ }^{14}$ — jak rzecz nazwano w powieści Na cmentarzu na wulkanie... (1864) — stany, z których nie wiadomo, co się wyłoni i kiedy.

Wiara Mochnackiego w semantyczną przezroczystość ruin opierała się na założeniu, że zniszczenie jest zawsze w jakimś stopniu odwracalne, w każdym razie nie zaciera bez reszty wiązań przeszłości z teraźniejszością. Ufał, że podobnie dzieje się także w świecie natury, rządzącej się przecież swoimi logicznymi prawami. Ruiny są dawne, a przez to już jakoś bezpieczne, zatrzymane i unieruchomione w stanie zniszczenia. Nikt z przechodniów nie żywi najmniejszych wątpliwości, że śpiewają one boleśnie czytelną pieśń: przemijania, marności, zmagania się ludzkiego ducha z naturą.

A gruzy i ruiny najświeższe? W Wieczorach drezdeńskich (1866), notesie sennych majaczeń wygnańca po styczniowej katastrofie, zapisane zostało nieme przerażenie: wszystko legło w ruinach, nic nie jest takie jak przedtem, a kamień, co na kamieniu nie pozostał, stacza się w przepaść z niepojętym dla ludzkiego ucha łoskotem:

I począłem przebiegać wzdłuż i wszerz obszary znane, po których przedeptałem był ścieżki niegdyś za tych szczęśliwszych czasów, gdym jeszcze wierzył w przyszłość. Pustkowie ciągnęło się na wsze strony, miasta w ruinach stały popalone, zawiewał je piasek płaszczem białym; zamki w gruzach sterczały, świecąc żebrami nagimi, kościoły po cegle obsypywały się powoli... wpośród ciszy słychać było kamienie staczające się na ziemię, a każdy z nich, padając, jękiem jakimś niezrozumiałym się odzywal ${ }^{15}$.

Z tego, co zostało zniszczone, nic i już nigdy nie da się uratować. Ale można budować gdzie indziej i co innego.

Ezy nasze nie odżywią tego, co na wieki umarło ${ }^{16}$.

Paraliżujące poczucie beznadziei wobec rozpadu starych form można przełamać, zagłębiając się w inną przeszlość lub inną przestrzeń - bo o przyszlości prorokować się nie da. Pytał Kraszewski:

Dlaczego nie mogąc doczekać jutra, nie zajrzysz do wczora? ${ }^{17}$

Odnajdując w sobie wzruszenie nad losami dawnych cywilizacji, zyska się pewność, że życie jest silniejsze od śmierci.

${ }^{14}$ J. I. Kraszcwski, Na cmentarzu-na wulkanie. Powieść wspótczesta, w: idem, Dzieła. Powrieści obyczajowe, red. J. Krzyżanowski [i in.], Kraków 1970, s. 8 (dalsze cytaty z tego wydania z paginacją w nawiasach).

${ }^{15}$ Idcm, Wieczory drezdeniskie, Lwów 1866, s. 139.

16 Idcm, Diabet, op. cit., s. 163.

${ }^{17}$ Idem, Wieczory drezdeńskie, op. cit., s. 163. 
W przedmowie do powieści Na cmentarzu - na wulkanie... Kraszewski wyjaśniał, dlaczego akcja utworu opatrzonego datą 1863 rozgrywa się pod włoskim niebem. Przekonywał, że wbrew pozorom - „dotyka mnóstwo zagadnień, w chwilach ciężkiej próby trapiących umysł człowieka” i „więcej czuć [w nim] nasz kraj niż obce”. Prosił o wyrozumiałość dla „wszelkiego pisma, które nosi na sobie datę nieszczęsną 1863 roku, bo w tej chwili łza wszystko przesiąknąc musiała i zamgliła niejedno". Sądzić by można, spodziewał się zarzutów krytyki i uprzedzał je, wypowiadając i oddalając najcięższy: „kogóż wśród bolesnej rzeczywistości jakakolwiek powieść obchodzić może" (5). Zdawał sobie sprawę, że nie tylko ta, zda się, oderwana od chwili obecnej, artystowska powieść, „fantastyczny obrazek” zawieść może oczekiwania czytelników, ale i wszelka w ogóle powieść z klasycznie prowadzoną fabułą nie byłaby w stanie udźwignąć doświadczenia powstań po dwakroć dławionych.

Powieść Na cmentarzu - na wulkanie... przeszła raczej bez echa. Bibliografie w każdym razie nie odnotowują ani jednej poświęconej jej recenzji. O tym, jak taka hipotetyczna recenzja mogłaby wyglądać, daje pewne wyobrażenie omówienie Witoloraudy... z roku 1841, w którym Aleksander Tyszyński nie bez zawodu przyjmował:

...poemat z fantazji Ariostowych i greckiego nieba osnuty (...) pieśń jakowąś estońską z dodatkiem naukowości szczegółów, ustęp Owidiuszowy - Mit słowem albo Przemianę litewską na wielką skalę śpiewaną ${ }^{18}$.

Krytyk piszący dwadzieścia parę lat później o Na cmentarzu — na wulkanie..., jeśli założyć, że w ogóle chciałby odnieść się do tej powieści serio, z podobnym sarkazmem wspomniałby zapewne i o włoskim tym razem niebie, i o fantazjach $z$ ducha Dantego, i o romansowym wątku. Wyliczałby, czego jego zdaniem w powieści zabrakło, podobny w tym do metody krytycznej Henryka Sienkiewicza, który o innej dobie w recenzji Krzyżaków 1410 (1874) Kraszewskiego dzielił się z czytelnikami swoim zdumieniem wobec dominacji wątków politycznych nad obyczajowymi przy jednoczesnej niespodziewanej nikłości opisu bitwy grunwaldzkiej ${ }^{19}$. Krytyk nasz próbowałby roztrząsnąć często podnoszone w krytyce lat sześćdziesiątych i siedemdziesiątych wobec tekstów „niczem z dolą kraju nie związanych” pytanie zasadnicze: „co nam dziś do tego”, Polakom? Właśnie, co nam do tego, zwłaszcza jeśli przyjdzie na myśl, by alegoryczny, estetyzujący obrazek, jakim jest Na cmentarzu - na wulkanie..., zestawić z powstaniowymi, pulsującymi aktualnością i warszawskimi realiami, powieściami Bolesławity?

Ani przywoływana Witolorauda..., pieśń pierwsza poematu Anafielas, ani Na cmentarzu na wulkanie... w twórczości Kraszewskiego nie są bynajmniej pozycjami szczególnie wywrotowymi. Wręcz przeciwnie, daje się w nich zauważyć typ wrażliwości pisarza, konsekwentnie znajdujący swoje ujście również w innych jego narracjach. Uważniejsza lektura twórczości Kraszewskie-

\footnotetext{
18 A. Tysz... [A. Tyszyński], Witolorauda. Powieśc z podań przez Józefa Ignacego Kraszeuskiego. Wilno 1840, „Biblioteka Warszawska" 1841 , t. 1 , s. 167.

19 Zob. [H. Sienkiewicz] (rec.) Krzẏ̇acy 1410, „Gazeta Polska” 1881, nr 246.

2) Zob. K. Kaszewski, (rec.) [W. Łoziński], Opowiadania Imi pana Wita Narwoja..., „Bluszcz” 1873, nr 45, s. 357.
} 
go, skupionej wokół szczególnie bolesnych dla Polski dat — powstania listopadowego i styczniowego — przekonuje, że najważniejsze dzieła pisarza do tych doświadczeń nawiązują nie wprost, lecz poprzez gęstą sieć odwołań do tradycji literackiej i historycznej. W latach trzydziestych, gdy Kraszewski dopiero ćwiczył pióro w licznych fantasmagoriach, humoreskach i powieściach historycznych, dojrzewały dzieła o nieusuwalnym piętnie katastrofy, spełniane w różnych wariantach o dekadę później. Mowa o autobiograficzno-obyczajowej powieści Poeta i śviat oraz epicko-poetyckim poemacie Anafielas. Natomiast od roku 1863 w twórczości Kraszewskiego widać dwie linie twórczości mocno ze sobą splecione, tj.: współczesne i historyczne powieści Bolesławity oraz utwory podpisywane nazwiskiem pisarza, wyrosłe z włoskich inspiracji, jak i z tłumaczenia Boskiej komedii.

Nie jest dla historyków literatury tajemnica, ze Kraszewskiemu z osobistych względów zależało na osłaniającej mocy pseudonimu tego, co sławi boleści ${ }^{21}$. W powieściach Bolesławity, których ambicją było tyleż dawanie świadectwa, ile kreowanie narodowej legendy, powstanie znajdowało się w centrum powieściowego świata. O tragedii Polaków mówiło się w nich dobitnie i wprost. W powieściach podpisywanych imieniem Józefa Ignacego Kraszewskiego przeciwnie katastrofa styczniowa pozostawała raczej w tle, a doświadczenie polskie okazywało się powtarzalne i wcale nie tak wyjątkowe. Powieści Bolesławity były intymną rozmową Polaków, prowadzoną w języku znaków i symboli głęboko osadzonych w niepowtarzalności polskiego losu. Kraszewski w o wiele większym stopniu liczył się z opinią cudzą. Świadczy o tym także powieść Na cmentarzu — na wulkanie... Wpisana jest w nią gra dystansów i wzajemnie sprzecznych prób zrozumienia włoskiej kultury i natury przez ludzi Włochom życzliwych, lecz nieodwołalnie obcych, gdyż przybywających z innych kręgów językowych i kulturowych. Sygnalizuje się tu zwątpienie autora, czy przeżycie powstaniowej katastrofy da się w ogóle wypowiedzieć w powieści homogenicznej; homogenicznej i co do ciągłej linii fabularnej, i co do perspektywy narracyjnej, i co do idiomu narodowej tradycji. Bolesławita siłą rzeczy wątpliwości takich żywić nie mógł.

Włoskie konteksty ważą nie tylko w powieściach Kraszewskiego o pierwszych chrześcijanach (Capreä i Roma - 1860; Rzym za Nerona - 1865), które - zdaniem Zygmunta Szweykowskiego — zwłaszcza po Irydionie Krasińskiego i Maratonie Ujejskiego można odnieść bezpośrednio do stosunków polsko-rosyjskich $^{22}$. Również Włochy Kraszewskiemu współczesne okazywały się obszarem piętrzącym pytania i obrazy. Antyczna alegoria nie była jedynym sposobem mówienia o sprawie polskiej w sposób metaforyczny i aluzyjny ${ }^{23}$. Podróż do Włoch stawała się zastępczą pielgrzymką do Polski, odbywaną na żywo - i na piśmie ${ }^{24}$. Nie tylko zresztą Kraszewski próbował odnaleźć tam elementy polskiego doświadczenia i spojrzeć na nie zupełnie innym okiem. Józef Kremer w swojej Podróży do Wtoch nie krył wyczulenia na „ruiny, gruzy, zwaliska” oraz prawdziwej

${ }^{21}$ Zob. W. Danek, Wstęp, w: J. I. Kraszewski, Dziecię Starego Miasta. Obrazek narysowany z natury, opr. W. Danck, Wrocław 1988 (BN I 71), s. XXXI-XXXII.

${ }^{22}$ Zob. Z. Szwcykowski, Klasyfikacja powieści Kraszewskiego pisanych po roku 1863, w: Ksiega ku czci Józefa Ignacego Kraszew'skiego, red. I. Chrzanowski, Łuck 1939, s. 129.

${ }_{23}$ Zob. A. Martuszewska, Pozytywistyczne parabole, Gdańsk 1997.

24 Zob. S. Burkot, Polskie podróżopisarstwo romantyczne, Warszawa 1988, s. 347-372. 
intencji tej pielgrzymki: aby choć z „sercem wstecz zwróconym” móc wyleczyć „umysł życiem codziennym zbolały" 25 .

Kraszewski w swojej powieści z 1863 roku przywoływał widok Neapolu — „cudowną harmonię wesela i rozkwitu”, wobec których „najsmutniejszy z ludzi” mógł się zapomnieć, napić „letejskiej wody zapomnienia i wzgardy na jutro". Zapomnieć, że możliwa jest zagłada, poczuć, jak silne jest życie. Obolała świadomość polska w pejzażu włoskim odnajdywała szansę, by bezpieczniej, lżej, pośrednio, powtórnie niejako doświadczyć emocji przywiezionych z kraju pogrążonego w postyczniowej nocy i przekonać się, że „choćby prysły ogniwa łańcucha, znów się gdzieś splotą” (94).

Eksperyment ten stał się udziałem bohaterki Kraszewskiego, hrabiny Adeli Żywskiej, którą straszliwa burza przeżyta na pizańskim cmentarzu radykalnie odmieniła i przywróciła do życia. Dziwiła się tylko bohaterka tej nagłej przemianie, pytając: „dlaczego my? dlaczego cmentarz, dlaczego burza i księżyc po niej?” (38). Burza i księżyc po niej; ogniwa łańcucha, choć gdzieś prysły, znów się gdzieś splotą. Trudno oczywiście zapomnieć, dlaczego właśnie ten kompleks uczuć zagrał w pejzażu włoskim. O tym właśnie jest ta powieść: o figurach udręczonej świadomości, o natręctwach polskiej wyobraźni - o burzy, cmentarzu, wulkanie, ruinach, agonii i zagładzie. Et in Arcadia ego; i w Arkadii spotykasz śmierć. I we Włoszech — Polskę, Rosję. I we Włoszech - śmierć.

To, co dla Polaków było doświadczeniem nieomal potocznym, dla cudzoziemców staje się towarem poszukiwanym. Występujący w powieści Na cmentarzu — na wnlkanie... Anglik nie mógł odżałować, że Wezuwiusz oglądał zawsze po wybuchu. Mój Boże, „gdyby wybuch był do kupienia, byłby się dawno oń z Włochami potargował" (58). Świadomie wzmacniał i teatralizował coś, co dla Polaków wymagało raczej wyciszenia: to on zaordynował iluminację pizańskiego cmentarza. Fantastyczny i piękny efekt budził powszechny entuzjazm, pozwalał na chwilę rozbudzić się leniwej wyobraźni, wygasłym emocjom. Tymczasem Polak, hrabia Zygmunt Żywski, pełnił wobec cudzoziemców rolę „wystudziciela i odczarownika” (38). Bo cóż jest w śmierci wyjątkowego?

Hrabia stał się w zawiązanej ad hoc wspólnocie turystów i pielgrzymów postacią egzotyczną, gorszącą pomysłami, szokującą głodnych wrażeń cudzoziemców swoją makabryczną wyobraźnią. A wyobraźnia ta była przecież zakorzeniona w polskiej codzienności. Toteż gdy Francuz niezobowiązująco rzucił pomysł, że jeśliby kto chciał popełnić samobójstwo, to rozpadlina z wrzącą lawą byłaby miejscem idealnym, hrabia zgodził się najzupełniej. Mimochodem tylko dodał, że zmieściłyby się tam doskonale samobójców tysiące (141). Kiedy Polak opowiadał o zwierzęcości ludzkiej natury, przeraził słuchaczy sformułowaniem, że przejawia się ona nie tylko w zachowaniach chorobliwych, okrutnych, patologicznych, lecz że zwierzęce są także --przywiązanie matki do dziecka, czyn bohatera sprawy ojczystej. Bohatera, oczywiście w polskim rozumieniu: czyli tego, który w uniesieniu zabija, nie zaś „dobroczyńcy ludzkości i anioła pociechy”. Ów brak szacunku dla życia i kult śmierci niepomiernie dziwiły Szweda. Dla niego herosi ci byli tylko „dumnymi zwycięzcami boleści, obojętnymi żebrakami, szyderskimi filozofami” (157).

${ }_{25}$ J. Kremer, Podróż do Wloch, t. 1, Warszawa 1878, s. 15. 
Tu jednak niespodziewanie Francuzi i Anglicy solidaryzowali się z Polakiem. Nudziła ich skandynawska moralistyka. Chcieliby, żeby Polak otworzył przed nimi swoją chorą, naznaczoną klęską duszę. To przynajmniej mogło być ciekawe i ożywcze niczym powieść grozy z pierwszej ręki. Polak jednak wykazał rezerwę wobec sugestii, by zostać niedźwiedziem w objazdowym cyrku Europy. Drwil, że zmuszają go, żeby „wywdzięczył się spowiedzią myśli za herbatę” (40). Powieść Kraszewskiego dotyczyła bowiem także blokady ekspresji po katastrofie, trudności opowiedzenia obcym, co się przydarzyło Polakom w XIX wieku — przy całej świadomości, że polski los nie jest aż tak wyjątkowy, jak skłonniśmy sądzić.

Scena w powieści, kiedy wszyscy mają wpisać się do księgi hotelowej, przedstawiajạc się $z$ imienia i nazwiska oraz krótko komentując wrażenia z nocy na cmentarzu, jest w istocie rozprawą o zahamowaniach w artykulacji traumatycznego przeżycia. Kraszewski obnażał stereotypy i klisze, przez które bohaterowie opisywali nadzwyczajne wydarzenie. Lecz - a jest to chyba najcenniejsza perspektywa tej książki - frazesy, niezręczności, banały pokazywał w całej ich znaczącej wielostronności i wieloznaczności.

W dziełach sztuki dostrzega się tylko jednostronną ich piękność, a wielostronne ich błędy i niedostatki; w geniuszach ich przerost w kierunku wyłącznym, kosztem pełnym władz; we wszystkim cielesne piętno znikomości i niedoskonałości (7).

Tematem powieści Kraszewskiego są bowiem w istocie wszelkiego rodzaju wypowiedzi niespełnione i nieudane. Nieudane, gdyż o gruzach i ruinach — nie malowniczych i romantycznych, lecz namacalnych i świeżych — nie sposób opowiadać w tradycyjny sposób. Jednakże nawet puste ogólniki, wyświechtane cytaty, komunały w stylu ars longa, vita brevis mówią wiele o ich użytkownikach, o tym, co chcieliby powiedzieć, a czego wyrazić nie umieją. Potrzeba ekspresji, wręcz spowiedzi, była równie wielka, jak nadzieja oczyszczenia, zaznania ulgi po klęsce paraliżującej władze ciała i umysłu. Sytuacja, w jakiej znaleźli się bohaterowie powieści Na cmentarzu - na wtılkanie..., wymagająca, by ludziom obcym opowiedzieć swoją biografię, stwarzała zresztą niepowtarzalną okazję do wypowiedzi szczerej i niezobowiązującej:

Nieznajomym właśnie mówi się lżej prawda, nie mamy interesu kłamać (56, podkr. - M. R.).

Lżej - nie znaczy: łatwo. Narracja hrabiny, wielokrotnie przerywana, odwodzona od głównego wątku dygresjami i komentarzami słuchaczy, toczy się meandrami, z trudem dobija końca. Swą opowieść Żywska zaczęła w Pizie, ciągnęła ją na Wezuwiuszu, a kończyła w dolinie, tuż po tym, jak cudem ocalona od śmierci uczestniczyła w samobójczo-ekspedycyjnym spektaklu swojego męża, który kazał spuścić się na linach do zionącego ogniem wnętrza wulkanu. Wszystko to wpłynęło na strukturę coraz bardziej poszarpanej, afabularnej opowieści podejmowanej przez hrabinę Żywską. 
Pomysł, by z kilku nowel ułożyć większą opowieść, świadomie nawiązujący do Dekameronu, pokazuje w istocie źródło atrakcyjności małych form narracyjnych: potrzebę szybkiego oderwania się od cierpienia i uodpornienia na nie.

...mamy prawo rozrywać się, jak owi florenccy tchórze, co się obawiali moru, bo i nasz wiek pełen jest zaraz i śmierci i oczu od nich odwrócić się nie godzi, aby trochę nabrać siły na cierpienie, które całą ściga ludzkość (54).

Tyle, że konwencja ta nie wystarczała. W powieści Kraszewskiego zapisana została namiętna dyskusja o relacjach między życiem a sztuką. Opinie rozkładały się zgodnie z podziałami geograficzno-politycznymi. Stwierdzenie niemieckiego artysty, iż „życie wyraża się całe w sztuce” doprowadziło polskiego hrabiego do wybuchu szału. On wiedział skądinąd, że sztuka nie dotyka „nędzy żywota”, jego „łachmańców”, że nawet „rozkrwawione” w greckiej tragedii serce musi być wprzód „W pachnącym spirytusie zamarynowane" (50). Temperatura dyskusji sięgnęła zenitu, gdy Herman Spauer oświadczył, że zgnilizna moralna i materialna nie ma z życiem nic wspólnego, i dlatego nie wchodzi w zakres sztuki.

- Kto waćpanu powiedział - porywczo zawołał pargaminowy hrabia - że zgnilizna życia nie ma? Ma ona je, ale inne, ale niedojrzane oczom waszym. Ty ją nazywasz kresem i skrajnym wyrazem, ona jest pierwszym bełkotem nowego języka, wrotami nowego świata. Spojrzyj przez mikroskop na zepsute serce człowieka i ser przegniły, zobaczysz tam światy... (51).

Sztuka zastana, tradycyjna jest bezradna wobec „embriona na gruzowisku” ${ }^{26}$, wobec „zgnilizny, fermentacji tajemniczych, bezkształtnych gnojowisk życia” (54) i wszelkich sił biologicznego zniszczenia. Sztuka nowa winna podjąć porażającą metaforę embriona na gruzach; dziecka porzuconego na czymś, co kształtów już nie ma - zanim jeszcze się urodziło, zanim więc przybrało ludzkie kształty. Procesy gnicia i umierania stanowią dla Polaków najbliższe doświadczenie. Stąd życie pod traumą zagłady mieści się z pewnością w kręgu tematów i pytań godnych sztuki. Nie tylko w imię prawdy czy szczerości nietamowanej ekspresji. Obrazy gnicia, zatraty, miazgi o czym świadczy i cała powieść Kraszewskiego, i jej zakończenie - mogą dawać strapionym pociechę, przywracać nadzieję. Na ostatniej karcie powieści narrator wyznaje:

Ileż to razy człowiek, gdy już zrozpaczy o sobie, gdy nie widzi żadnej nadziei, stoi, nie wiedząc sam o tym, u wrót, które go dzielą od pokoju i szczęścia! (188)

Powieść o świecie w proch obróconym, gdyby się komu naprawdę powiodła, wystawiałaby swego czytelnika na próbę rozpaczy granicznej. Po której wrota muszą się wreszcie uchylić.

Tektonika powieści - świat cywilizacji, natury, ludzi - ulega procesom rozpadu i odrodzenia w formach najmniej spodziewanych i wzajemnie przemieszanych. Powieść o wulkanie jako symbolu katastrofy zagrażającej wszystkim tym światom stawia pytanie o skutki zerwania ciągłości, przerwania łańcucha istnienia.

${ }^{26}$ J. I. Kraszewski, $M \gamma$ i oni..., op. cit., s. 15. 
W świecie wyobraźni romantycznej ruina gwarantowała ciagłość dziedzictwa i doświadczenia potocznego. Była pomnikiem przeszłości, czekającej na wyroki przyszłości. Gruzy, w wyobraźni tej bodaj nieobecne, zestawiane $\mathrm{z}$ hieratycznymi ruinami okazywały się - miejscem milczącym posępnie i pustym. Nie było już czego w nich szukać. Podróż do Włoch stawała się nieodzowna dla podtrzymania nadziei.

Czemu nie płakałeś nad Rzymem, gdy się padać zdawał, mając się odrodzić? Czemu nie rozpaczałeś nad Kartagą i nad Troją? Przecież z gruzów wyniesione bogi, i wyszli starce i wybiegły dzieci, przeszłość i przyszłość, wspomnienie i nadzieje... przecież $\mathrm{z}$ mogil powstawały trupy, $\mathrm{z}$ ruin grody... a nic nie umarło... 27

Wyobraźnia Józefa Ignacego Kraszewskiego rewaloryzuje przeciwstawienie ruin i gruzów. Polskie szczątki wielkości pisarz starał się widzieć w perspektywie badacza dziejów, by przezwyciężyć samotność i rozpacz. Dlatego na towarzysza swoich wieczornych wędrówek wybrał Dantego, który „przeczuł (...) i doświadczył wszystkie wygnania boleści”,28, pokazał, że „cierpienie wiele może”; „więcej wydobywa z człowieka nizeli pokój, który usypia” ${ }^{29}$. Cierpienie sprowadza i potwierdza heroiczną wiarę w moc życia wbrew wszystkiemu. Na cmentarzu - na wulkanie, powieść o obolałej wyobraźni szukającej ukojenia wśród antycznych ruin staje się hymnem na cześć życia - życia, jak je określił hrabia, „innego, niedojrzanego oczom innych” (50). Życia jako tajemnego odradzania się przez śmierć i katastrofę.

\footnotetext{
${ }^{27}$ Idem, Wieczory drezdeńskie, op. cit.

28 Ibidem, s. 5.

29 Ibidem, s. 30.
} 